BMJ Open

Sport \&

Exercise

Medicine

\title{
Whose sport is it anyway? Sport taxonomy in manuscripts, some clarification required
}

\author{
Nash Anderson (D) , ${ }^{1}$ Reidar P Lystad (D) ${ }^{2}$
}

To cite: Anderson N, Lystad RP. Whose sport is it anyway? Sport taxonomy in manuscripts, some clarification required. BMJ Open Sport \& Exercise Medicine 2021;7:e001256. doi:10.1136/ bmjsem-2021-001256

Accepted 3 December 2021

Check for updates

(C) Author(s) (or their employer(s)) 2021. Re-use permitted under CC BY-NC. No commercial re-use. See rights and permissions. Published by BMJ.

${ }^{1}$ Tuggeranong Chiropractic Centre, Canberra, Australian Capital Territory, Australia ${ }^{2}$ Australian Institute of Health Innovation, Macquarie University, Sydney, New South Wales, Australia

Correspondence to Mr Nash Anderson; nash.anderson@gmail.com
To maximise their utility, injury and illness surveillance data must be consistently collected and accurately classified. To achieve this goal, research groups have published 11 sport-specific or setting-specific consensus statements on the methods of recording and reporting of epidemiological data on injury and illness in sport to date. ${ }^{1}$ However, all this effort may be undermined if the sporting activities are not accurately described and classified in the first instance. Here at British Open Journal of Sport and Exercise Medicine (BOSEM), we can educate our editorial board and institute editorial policies to ensure adequate reporting in future publications. But how can we simplify this process for authors, peer reviewers, and editors to ensure a sustained shift in best practice across the whole discipline? This editorial aims to highlight the issue and start a conversation about how we, as a community, can resolve it.

\section{WHAT'S THE ISSUE?}

Sports are not always accurately identified in the literature. In a literature review of 'volleyball', the authors found many studies did not specify the type of volleyball. ${ }^{2-7}$ Indoor volleyball and beach volleyball have different injury mechanisms and demands on their players. For instance, indoor volleyball is played indoors on a hardcourt with six shod players per team, whereas beach volleyball is played on sand with two barefoot players per team. ${ }^{8}$ Similarly, there are also inconsistencies and a lack of clarification in the literature on 'football', which is inconsistently used to refer to a wide range of codes, including association football, American football, rugby league, rugby union, Australian football, and Gaelic football, to name but a few examples.

If authors do not specify the sport or context, there is a risk that readers may assume the sport incorrectly. There is particular concern that not everyone has the expertise to critically discern which sport is being discussed, resulting in misinterpretations and misapplications of research findings, including suboptimal injury prevention strategies. To minimise the risk of unintended and inappropriate use of data, we must convey information clearly and in a way that our audience can understand.

\section{WHY DOES THIS LIKELY OCCUR?}

Popularity bias is a likely contributing factor. Injury and illness surveillance data are produced by researchers from all corners of the world. Take, for example, the diversity of the current BOSEM editorial board, a team of experienced and emerging academics and clinicians representing 15 countries from 6 continents. ${ }^{9}$ The predominance and popularity of individual sports vary considerably across countries and regions. Authors often default to long-standing and dominant versions of a sport in particular locations. For example, authors in the USA may use the term 'football' when referring to American football, whereas Australian authors using the same term may mean rugby union in the state of New South Wales, rugby league in the state of Queensland, or Australian football in the state of Victoria.

Another important factor is the current lack of a standardised taxonomy of sporting activities, making it difficult for journals to provide specific guidance to authors. There have been several attempts to classify sports based on, for example, motor skills and functional demands, medical or physiological characteristics, required equipment, and socialpsychological factors. ${ }^{10}{ }^{11}$ But these are typically designed for a specific research purpose, and neither are good candidates for a comprehensive taxonomy of sports. There is also the US National Library of Medicine's controlled vocabulary thesaurus, the Medical Subject Headings (MeSH) database, which is used to index articles in the MEDLINE/ PubMed database ${ }^{12}$; and the WHO's International Classification of Diseases and Related Health Problems (ICD), which includes a set of activity codes. ${ }^{13}$ However, the entries categorised under the MeSH term 'Sports' and the 
ICD activity codes are woefully inadequate as a taxonomy of sports.

\section{WHAT CAN WE DO ABOUT IT?}

It is an unwritten rule in academic circles that the onus is on authors investigating less dominant sports (eg, beach volleyball) to clarify this in their article. However, relying on unwritten rules is unlikely to resolve the issue. There needs to be a shift towards a general expectation that all authors describe the sport or context with sufficient precision in their publications, regardless of the dominance of the sport.

A relatively simple solution is to improve journals' instructions and guidelines to authors. These should require authors to describe sporting activities with sufficient detail to avoid ambiguity. For instance, 'rugby' should be characterised as rugby union, rugby league, rugby sevens, etc, whichever the case may be. Journals will need to educate their handling editors to actively screen manuscripts for compliance with the guidelines. Ideally, the editors-in-chief of leading sports and exercise medicine and science journals should develop and implement the specific guidelines to authors jointly.

A more involved solution is to develop a standardised taxonomy of sports. To be fit for purpose, a new taxonomy of sports must be able to classify the estimated 3000+ sports out there in a useful and efficient manner. It also must have enough flexibility to be able to incorporate new and emerging sports. To successfully develop the equivalent of a Dewey Decimal Classification for sports, we would need a multidisciplinary effort comprising sports and exercise researchers and information scientists. This is an endeavour that must be supported by those involved in science and practice of sport in the broadest sense.

\section{RECOMMENDED RESOURCE}

BMJ's Resources for Authors', 2021 URL: https://www. bmj.com/about-bmj/resources-authors.

Twitter Nash Anderson @Sportmednews and Reidar P Lystad @RLystad

Acknowledgements Evert Verhagen provided feedback on the draft manuscript.

Contributors NA and RPL, drafted the first version and approved the final version of this editorial.

Funding The authors have not declared a specific grant for this research from any funding agency in the public, commercial or not-for-profit sectors.
Competing interests NA is an editorial board member of BMJ Open Sports \& Exercise Medicine.

Patient consent for publication Not applicable.

Ethics approval This study does not involve human participants.

Provenance and peer review Not commissioned; externally peer reviewed.

Open access This is an open access article distributed in accordance with the Creative Commons Attribution Non Commercial (CC BY-NC 4.0) license, which permits others to distribute, remix, adapt, build upon this work non-commercially, and license their derivative works on different terms, provided the original work is properly cited, appropriate credit is given, any changes made indicated, and the use is non-commercial. See: http://creativecommons.org/licenses/by-nc/4.0/.

\section{ORCID iDs}

Nash Anderson http://orcid.org/0000-0002-1786-8805

Reidar P Lystad http://orcid.org/0000-0003-0506-0902

\section{REFERENCES}

1 Bahr R, Clarsen B, Derman W, et al. International Olympic Committee consensus statement: methods for recording and reporting of epidemiological data on injury and illness in sport 2020 (including STROBE extension for sport injury and illness surveillance (STROBE-SIIS)). Br J Sports Med 2020;54:372-89.

2 Watson A, Biese K, Kliethermes SA, et al. Impact of in-season injury on quality of life and sleep duration in female youth volleyball athletes: a prospective study of 2073 players. Br J Sports Med 2021:55:912-6.

3 Witvrouw E, Cools A, Lysens R, et al. Suprascapular neuropathy in volleyball players. Br J Sports Med 2000;34:174-80.

4 Skazalski C, Kruczynski J, Bahr MA, et al. Landing-related ankle injuries do not occur in plantarflexion as once thought: a systematic video analysis of ankle injuries in world-class volleyball. $\mathrm{Br} J$ Sports Med 2018:52:74-82.

5 de la Cruz-Márquez JC, Cueto-Martín B, de la Cruz-Campos JC, et al. Electrocardiographic profile of volleyball players. Br J Sports Med 2011;45:540.

6 Hashimoto Y, Yamashita T, Hamu Y, et al. Anti-Doping activites of volleyball in Japan. Br J Sports Med 2011;45:547.

7 Kulig K, Landel R, Chang Y-J, et al. Patellar tendon morphology in volleyball athletes with and without patellar tendinopathy. Scand $J$ Med Sci Sports 2013;23:e81-8.

8 AVP. Beach Volleyball vs indoor Volleyball: rules and regulations, 2019. Available: https://avp.com/news/beach-volleyball-vs-indoorvolleyball-rules-and-regulations/ [Accessed 28 Jul 2021].

9 Verhagen $\mathrm{E}$, Oliveira $\mathrm{F}$, Ahmed $\mathrm{OH}$, et al. Let us introduce ourselves, \#WeAreBOSEM. BMJ Open Sport Exerc Med 2021;7:e001171.

10 Terwiel S, Rauthmann JF, Luhmann M. Using the situational characteristics of the DIAMONDS taxonomy to distinguish sports to more precisely investigate their relation with psychologically relevant variables. PLoS One 2020;15:e0241013.

11 Pietsch S. The different point of View-A Visual-Spatial taxonomy for sports. J Athl Enhanc 2018;7.

12 US National Library of Medicine-National Centre for Biotechnology Information. Sports - MeSH - NCBI. [online], 2021. Available: https:// www.ncbi.nlm.nih.gov/mesh/68013177 [Accessed 27 Aug 2021].

13 Who.int. Classification of Diseases (ICD). [online], 2021. Available: https://www.who.int/standards/classifications/classification-ofdiseases [Accessed 14 Sep 2021]. 